\title{
2 Expression of common biomarkers in Antarctic krill (Euphausia 3 superba) exposed to an organochlorine contaminant
}

\author{
4 Amanda Dawson $^{1}$ (D) Anita Poulsen ${ }^{2} \cdot$ Wilhelmina Huston $^{3} \cdot$ Susan Bengtson Nash $^{1}$
}

A3

A6

A9

Received: 4 April 2017/Revised: 25 July 2017/Accepted: 12 September 2017

(C) Springer-Verlag GmbH Germany 2017

Abstract Persistent organic pollutant (POP) contamination of Polar Regions continues to present a major ecological challenge and an environmental stressor to local biota. Antarctic krill (Euphausia superba) are a keystone species of the Antarctic sea ice ecosystem. Krill have repeatedly been found to accumulate a diverse array of POPs and thereby serve as vectors of these to the remainder of the Antarctic food web. $p, p^{\prime}$-Dichlorodiphenyldichloroethylene $\left(p, p^{\prime}\right.$-DDE) is a dominant POP compound accumulating in Antarctic krill and higher trophic level predators. Recently, $p, p^{\prime}$-DDE uptake dynamics, associated behavioural and developmental toxicity were evaluated in this species. The present study investigated the response of enzymes with known roles in detoxification (glutathione $S$-transferase, GST and cytochrome P450 2B, CYP2B), neurotoxicity (acetylcholinesterase, AChE) and oxidative stress (glutathione peroxidase GPx) in Antarctic krill exposed to $p, p^{\prime}$ DDE. CYP2B was not detectable in Antarctic krill. No strong concentration responses resulted from the exposure to $p, p^{\prime}$-DDE. These findings do not provide evidence for an activated detoxification response to this compound via the tested biochemical pathways in Antarctic krill. This is the first time that GST, AChE and GPx have been characterised

Amanda Dawson

amanda.dawson@griffithuni.edu.au

1 Griffith School of Environment, Environmental Futures Research Institute, Griffith University, 170 Kessels Road, Nathan, QLD 4111, Australia

2 Department of Earth, Ocean and Atmospheric Science, Florida State University, 117 N. Woodward Ave, Tallahassee, FL 32306, USA

3 Faculty of Science, School of Life Sciences, University of Technology Sydney, 15 Broadway, Ultimo, NSW 2007, Australia in this species following pollutant exposure. Further research with additional pollutants and compound mixtures is necessary to assess the practical role of these enzymes as biomarkers of pollutant exposure in Antarctic krill. These first exploratory findings present a valuable contribution to a critical knowledge gap in polar ecotoxicology, namely the comparative sensitivity of polar organisms relative to temperate and tropical counterparts.

Keywords Crustacean - Antarctic krill - Antioxidant enzymes · Biomarker - Detoxification · Persistent organic pollutant

\section{Introduction}

Despite the apparent pristine nature of Antarctica and it's remoteness from industry, persistent organic pollutants (POPs) have been detected in Antarctic biota since the 1960s (George and Frear 1966; Sladen et al. 1966). The presence of POPs so far from their sources can largely be attributed to long range environmental transport pathways and more recently in situ human activities (Wild et al. 2015). Once deposited at high latitudes, the volatility of POPs is markedly reduced (Wania and MacKay 1996), with the Earth's poles proposed as major "environmental sinks" for most of the world's remaining POPs.

Antarctic krill, Euphausia superba, a swarming Euphausiid crustacean, are a commercially valuable Southern Ocean keystone species. Krill are a sympagic species that grazes on phytoplankton, with their abundance and distribution closely linked to the Antarctic sea ice extent (Flores et al. 2012). Despite being one of the most abundant species on the planet, there are concerns for the long-term survival of krill stocks in the face of climate change and over-fishing. Several studies 
have documented decreased krill abundance and density linked with reduced sea ice extent, whilst ocean acidification is projected to have a dramatic effect on recruitment and species survival if carbon emissions are left unmitigated (Kawaguchi et al. 2011). The pivotal ecological role of krill means that a biomass decline would have far-reaching repercussions for the reliant ecosystem (Atkinson et al. 2004; Nicol et al. 2008).

Diverse profiles and notable concentrations of POPs, including organochlorine compounds, have repeatedly been detected in Antarctic krill ( Corsolini et al. 2002a, b, 2006; Bengtson Nash et al. 2008). $p, p^{\prime}$-Dichlorodiphenyldichloroethylene $\left(p, p^{\prime}\right.$-DDE) is one of the dominant compounds accumulating in Antarctic krill and higher trophic level Antarctic predators (Bengtson Nash et al. 2008, 2013; Waugh et al. 2014). $p, p^{\prime}$-DDE occurs in the environment as the most stable metabolite of the organochlorine compound dichlorodiphenyltrichloroethane, which is more commonly known as the pesticide DDT. Despite the basal position of krill in the Antarctic food web, investigations of the toxicological sensitivity of the species remain limited. Recently, the development of a series of krill-based toxicological exposure assays permitted the first evaluation of $p, p^{\prime}$-DDE toxicity in both larval and adult krill stages (Poulsen et al. 2011, 2012b, 2013). Antarctic krill exposed to $p, p^{\prime}$-DDE exhibited behavioural responses and altered larval development (Poulsen et al. 2011, 2012a, b, 2013). Nothing is currently known about the underlying biochemical mechanisms of $p, p^{\prime}$-DDE toxicity in Antarctic krill and their capacity for detoxification. It has often been proposed that the evolutionary isolation and underdeveloped detoxification systems of Antarctic species leave them vulnerable to the toxicity of anthropogenic contaminants (Chapman and Riddle 2005; Corsolini 2009). Further, polar organisms are characterised by gigantism and slow metabolism, making conventional toxicity evaluation time frames unsuitable and limiting comparison to temperate or tropical counterparts (King and Riddle 2001).

In crustaceans, the metabolism of foreign contaminants, or xenobiotics, predominantly occurs in the digestive gland and it is thought to proceed in a similar manner as in mammals. Detoxification is often described in three functional stages. Phase I, where xenobiotics are identified and transformed into more soluble metabolites, is primarily governed by a superfamily of specialised enzymes (cytochrome P450, CYPs). Phase II detoxification is performed by a variety of non-specific detoxification enzymes with the role of further increasing metabolite solubility. Finally Phase III metabolism ensures effective excretion of by-products (Livingstone 1991; Rewitz et al. 2006).

Glutathione $S$-transferases (GST) are a family of generalist Phase II detoxifying enzymes. Up-regulation of GST activity has previously been observed in association with insecticide resistance (Enayati et al. 2005) and exposure to POPs (Hoarau et al. 2001; Gaume et al. 2014). Throughout the detoxification process, as well as through general metabolism, reactive oxygen species are produced which carry the potential to cause oxidative stress. Oxidative stress can induce up-regulation of antioxidant enzymes, for example glutathione peroxidase (GPx), which are responsible for neutralising reactive oxygen species to prevent associated harmful effects such as lipid peroxidation and DNA damage (Livingstone 1991).

DDT is a neurotoxin which affects crustacean sodium channels, subsequently leading to hyperactivity and death (Sánchez-Bayo 2012). A typically used marker for neurotoxicity is acetylcholinesterase (AChE) activity. The inhibition of AChE impairs the transmission of signals between neurons, and is commonly known to be specific to organophosphate and carbamate pesticides (Hassall 1990). However previous research has reported on AChE inhibition in response to organochlorine compounds, including DDT (Martinez-Tabche et al. 1999; Galindo-Reyes et al. 2000; Bhavan and Geraldine 2001). AChE inhibition may thus provide an easily measurable marker for exposure to DDT and its metabolites in krill.

Enzymes have been widely used as biomarkers of chemical exposure, with CYPs, GST, GPx and AChE some of the most frequently used. Biochemical screening is often more cost-effective than chemical analysis, permitting broad scale application. Further, molecular change signals a biological response to chemical exposure and serves as an early warning of possible toxic effects (Bengtson Nash et al. 2006). Successful implementation of the biomarker approach requires that a direct relationship is established between chemical exposure and expression of the target biomarker (Jemec et al. 2010). Nothing is currently known about the response of sub-cellular biomarkers to chemical exposure in Antarctic krill. The purpose of this exploratory study is to investigate the response of four commonly used biomarkers GST, CYP2B, GPx and AChE to sublethal $p, p^{\prime}-$ DDE exposure in Antarctic krill. The suitability of these enzymes as potential biomarkers of sub-cellular effects in Antarctic krill is discussed, thereby contributing new knowledge to the critical research gap surrounding the detoxification capabilities of endemic Polar species.

\section{Methods}

\section{Exposure design}

The experimental design used for exposure of Antarctic krill to $p, p^{\prime}$-DDE is further described in (Poulsen et al. 2012a). Adult Antarctic krill were collected in the austral summer of 2006 from the eastern Antarctic sector $\left(66^{\circ} \mathrm{S}\right.$ 
$\left.80^{\circ} \mathrm{E}\right)$. Animals were housed at the Australian Antarctic Division krill culturing facilities, Tasmania, Australia until $p, p^{\prime}$-DDE exposure in 2007. The weight of exposed krill ranged from 364 to $927 \mathrm{mg}$ wet weight. Prior to exposure krill were acclimatised for $24 \mathrm{~h}$ under experimental conditions without food. Five krill were housed in 5-L glass beakers. Exposure seawater was collected from Bruny Island, Tasmania, and pre-filtered to $0.2 \mu \mathrm{m}$. Exposure solutions were spiked with $p, p^{\prime}$-DDE using acetone as a solvent carrier (in a final concentration of $0.03 \mathrm{~mL} \mathrm{~L}^{-1}$ ). Antarctic krill were exposed for $96 \mathrm{~h}$ using five $p, p^{\prime}$-DDE exposure treatments $\left(1,5,10,15\right.$, and $\left.20 \mu \mathrm{g} \mathrm{L}^{-1}\right)$, plus an additional seawater-only and a seawater-acetone $(0.03$ $\mathrm{mL} \mathrm{L}^{-1}$ ) control. Exposure media was renewed every $24 \mathrm{~h}$. The setup included three replicate 5 -L test beakers for each treatment and control to ensure statistical power. Krill were not fed for the duration of the experiment. Upon the end of the experiment all animals were euthanised by placing in liquid nitrogen and samples were stored at $-80{ }^{\circ} \mathrm{C}$ until the time of analysis. The experiment was duplicated within 1 month, with krill from the first experiment used for GST, GPx and $\mathrm{AChE}$ analysis and krill from the second experiment used for CYP2B analysis.

\section{Internal concentrations}

The actual concentrations of seawater and those accumulated by krill were not measured in the present experiment. We confirmed in a supporting experiment conducted under identical conditions that actual seawater concentrations were in accordance with nominal concentrations (Poulsen et al. 2012a). We also confirmed in the supporting experiment that krill uptake of $p, p^{\prime}$-DDE took place throughout $96 \mathrm{~h}$ of exposure by measuring the concentrations in krill bodies (Poulsen et al. 2012a). The uptake was concentration dependent and linear over $96 \mathrm{~h}$. The method used to measure $p, p^{\prime}$-DDE in krill bodies is destructive and would have rendered enzyme analysis impossible. The concentrations of $p, p^{\prime}$-DDE in exposure media and internal body residues at $96 \mathrm{~h}$ as measured in the supporting experiment are given in Table 1. As the concentrations were not measured in the present experiment, the exposure concentrations will continue to be referred to by their nominal concentrations from here on $\left(1,5,10,15\right.$ and $\left.20 \mu \mathrm{g} \mathrm{L}^{-1}\right)$.

\section{Sample preparation of sub-cellular fractions}

\section{Cytosolic fraction}

Crustacean digestive glands are highly autolytic. In order to minimise the chances of enzyme degradation during

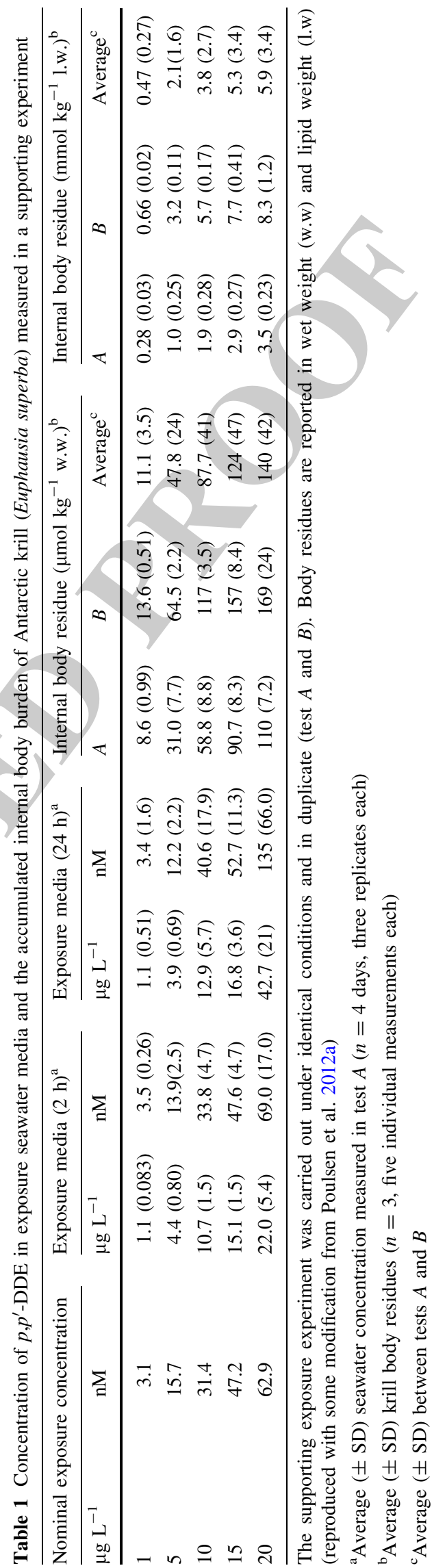


sample preparation, whole body extracts were used for enzyme analysis. Two krill from each replicate of the first experiment were pooled for GST and GPx biochemical assays. The krill were decapitated; heads were kept for AChE analysis. The bodies were homogenised in approximately $10 \mathrm{~mL}$ phosphate buffer $(100 \mathrm{mM}$ potassium phosphate $\mathrm{pH}$ $7.4, \quad 0.1 \mathrm{mM}$ phenylmethylsulfonyl fluoride, $100 \mathrm{mM}$ potassium chloride and $1 \mathrm{mM}$ ethylenediaminetetraacetic acid, modified from Koenig et al. (2013)) with a hand-held electric homogeniser. The homogenate was centrifuged at $12,000 \times g$ for $90 \mathrm{~min}$ at $4{ }^{\circ} \mathrm{C}$, and the supernatant was recentrifuged at $100,000 \times g$ for $90 \mathrm{~min}$ at $4{ }^{\circ} \mathrm{C}$. The resulting supernatant (cytosol) was kept on ice until use.

\section{Post-mitochondrial fraction}

Krill heads were pooled to determine AChE activity (approximately $0.24 \mathrm{~g}$ wet weight). Homogenisation was carried out according to Minutoli et al. (2002). Samples were homogenised in a $0.1 \mathrm{M}$ Tris- $\mathrm{HCl} \mathrm{pH} 8,0.1 \%$ triton buffer with $1 \mathrm{~mL}$ for every $0.06 \mathrm{~g}$ tissue. The homogenate was centrifuged for $12,000 \times g$ for $10 \mathrm{~min}$ at $4{ }^{\circ} \mathrm{C}$ and the resulting supernatant (post-mitochondrial fraction) was stored on ice until needed.

\section{Microsomal fraction}

Five krill from each replicate of the second experiment were pooled for CYP2B activity. Microsomes were prepared as per the cytosolic fraction, and the resulting pellet (microsomes) from the $100,000 \times g$ centrifuge was kept on ice until use.

\section{Biomarker assays}

Biomarker assays were carried out in triplicate with positive and negative controls using a BioRad microplate spectrophotometer or a PolarStar Optima microplate reader. GST activity was quantified by measuring the reaction of $1 \mathrm{mM}$ 1-chloro-2,4-dinitrobenzene and $1 \mathrm{mM}$ reduced glutathione (Habig et al. 1974) with $150 \mu \mathrm{L}$ of sample. The absorbance at $340 \mathrm{~nm}\left(25^{\circ} \mathrm{C}\right)$ was recorded for $5 \mathrm{~min}$. GPx was determined using a commercial assay kit (Cayman Chemical). The decrease in absorbance was measured at $340 \mathrm{~nm}\left(25^{\circ} \mathrm{C}\right)$ for $5 \mathrm{~min}$. AChE activity was determined by measuring the

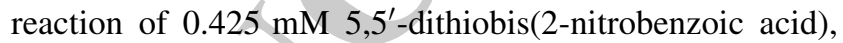
$1 \mathrm{mM}$ acetylthiocholine iodide and $10 \mu \mathrm{L}$ of sample at $405 \mathrm{~nm}\left(25^{\circ} \mathrm{C}\right)$ for $10 \mathrm{~min}$ (Ellman and Courtney 1961). Blank activity was measured in the absence of post-mitochondrial fraction. CYP2B activity was determined using the pentoxyresorufin $O$-dealkylase assay. The increase in the fluorescence of $0.25 \mathrm{mM}$ of NADPH, $6.2 \mu \mathrm{M}$ pentoxyresorufin and $50 \mu \mathrm{L}$ of sample was measured at $30^{\circ} \mathrm{C}$ for
$10 \min (\lambda$ excitation $=537 \mathrm{~nm}$ and $\lambda$ emission $=583 \mathrm{~nm})$. The reaction was calculated with a resorufin sodium salt standard curve with seven concentrations $(0-80 \mathrm{nM})$ (Koenig et al. 2013). Protein content was determined using bovine serum albumen as a standard, ranging from 0 to $1000 \mathrm{mg} \mathrm{mL}^{-1}$. The reaction was measured at $562 \mathrm{~nm}$.

\section{Statistical analysis}

All measurements are reported as mean \pm standard error (SE) unless otherwise stated. GST and GPx activity is expressed as nmol $\mathrm{min}^{-1} \mathrm{mg}$ protein ${ }^{-1}$; AChE activity is expressed in pmol $\min ^{-1} \mathrm{mg}$ protein ${ }^{-1}$. Homogeneity of variance was assessed using a Levene Test and data were checked for normality using a Shapiro-Wilk test. AChE activity was analysed using a Kruskal-Wallis test. GST activity was analysed using Welch's ANOVA with Dunnett's post hoc and GPx responses before exposure concentrations were analysed using a one-way ANOVA with a Tukey post hoc test. Pearson's or Spearman's correlation was used to evaluate linear relationships between concentrations and enzyme responses. All statistical analyses were performed in SPSS, Inc., version 20.0 with $p$ values of $<0.05$ considered to be statistically significant. The acetone solvent control did not differ significantly from the seawater control; therefore both controls were pooled for the analysis (student's $t$ test, GST $t 16=-0.26, p=0.800$, GPx $t 16=-1.18, p=0.280$, AChE $t 9.5=-1.4, p=0.193)$.

\section{Results}

There was no mortality of any krill throughout the exposure period. Of the enzymes measured, none produced a $p, p^{\prime}$ DDE concentration-dependent response at the range tested in Antarctic krill $(r=0.190, n=63, p=0.135 ; r=0.246$, $n=63, p=0.052 ; r s=-0.02, n=57, p=0.887$ for GST, GPx and AChE, respectively). CYP2B was not detectable in these specimens. Glutathione $S$-transferase activity was elevated at all $p, p^{\prime}$-DDE exposure concentrations compared to the control $(47.5 \pm 2.67)$ (Fig. 1); however, no treatment induced a significant increase in GST activity in Antarctic krill $(F(5,22.33)=1.92, p=0.130)$. Interestingly the 1 and $20 \mu \mathrm{g} \mathrm{L}^{-1}$ concentrations expressed higher GST activity than the 5, 10 and $15 \mu \mathrm{g} \mathrm{L}^{-1}$. Treatment activity ranged from $48.71 \pm 2.34$ for exposure to $15 \mu \mathrm{g}$ $\mathrm{L}^{-1}$ to $63.24 \pm 5.93$ for $20 \mu \mathrm{g} \mathrm{L}^{-1}$. Acetylcholinesterase activity was not correlated with $p, p^{\prime}$-DDE exposure concentration. All exposure concentrations displayed lower activity than the control; however, no treatment was significantly inhibited by $p, p^{\prime}$-DDE in Antarctic krill $(H(5)=$ $5.03, p=0.412$, range $0.22 \pm 0.01$ to $0.25 \pm 0.02$ ). Glutathione peroxidase activity ranged from $14.8 \pm 1.24$ to 


\section{GST}
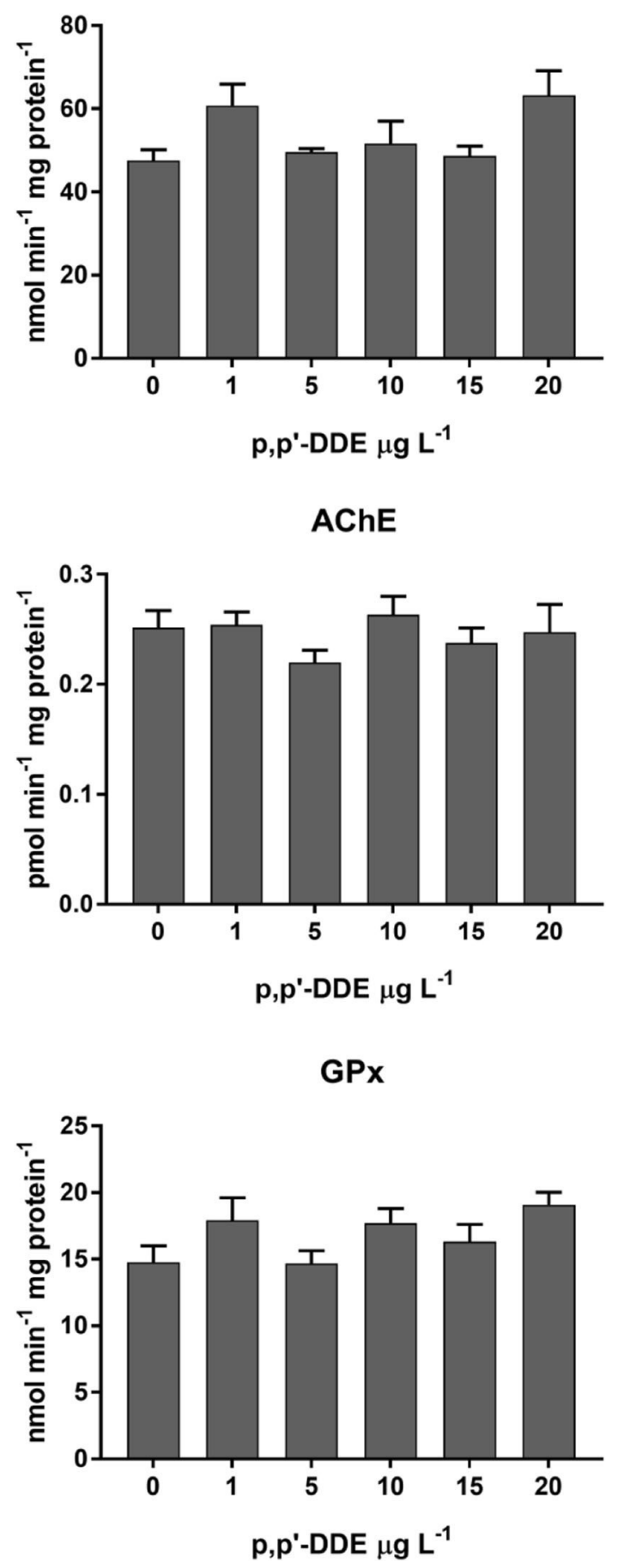

Fig. 1 Activity (mean \pm S.E) of the three enzymes, Glutathione S-transferase (GST), Acetylcholinesterase (AChE) and Glutathione peroxidase (GPx), in response to $p, p^{\prime}$-DDE exposure in Antarctic krill (Euphausia superba). The pooled control is represented by the $0 \mu \mathrm{g}$ $\mathrm{L}^{-1}$ treatment. Graphics generated in Graphpad Prism 7

$19.06 \pm 0.98$. There was no significant change in activity for possibly suggesting that there was an underlying factor, such as gender, which remained unaccounted for.

\section{Discussion}

Glutathione $S$-transferase

The observation of a slight induction of GST activity may suggest that a generic detoxification response was triggered in the krill, however with limited capacity. Indeed a basic capacity for detoxification of chemical exposure may explain the declining potency of $p, p^{\prime}$-DDE noted during the exposure period (Poulsen et al. 2012a). After initial exposure to $p, p^{\prime}$-DDE, krill mobility was observed to decrease and as the experiment progressed the response lessened (Poulsen et al. 2012a). $p, p^{\prime}$-DDE is the most stable metabolite of DDT and it is unknown if this product is further metabolised in Antarctic krill, as is the case for some freshwater invertebrates (Lotufo et al. 2000; Lydy et al. 2000). Based on the present assay results, it does not appear that GST plays a major role in $p, p^{\prime}$-DDE detoxification in this species. These findings contrast the DDT detoxification pathways known in other species. For example GST causes insecticide resistance and is responsible for the detoxification of DDT to $p, p^{\prime}$-DDE, in insects and freshwater invertebrates (Clark and Shamaan 1984; Livingstone 1991). Further, increased GST activity is exhibited by molluscs exposed to $p, p^{\prime}$-DDE, in similar exposure concentrations to those used in this study (Hoarau et al. 2001). Although, the latter study found that only one specific class of GSTs were induced by $p, p^{\prime}$-DDE, these have not yet been described in Antarctic krill (Clark et al. 2011).

A drawback of the use of GST as a biomarker is the variability of baseline levels demonstrated in previous studies (e.g. Koenig and Solé 2012). Being a generalist family of enzymes, GST induction is triggered by many endogenous and exogenous stimuli such as fasting, gender, vertical migration, season, metabolic rate, etc. (Jemec et al. 2010, 2012; Tremblay et al. 2010). This variability can mask the response GST to xenobiotic exposure therefore further characterisation is needed, but was beyond the scope of this study. The effects of environmental stimuli can be reduced by sufficient acclimation to stable laboratory conditions (Jemec et al. 2010). The present experiment included a $24 \mathrm{~h}$ acclimation period to test conditions. It cannot be ruled out that the variability exhibited in krill in this study resulted from environmental factors. More likely the observed variation was caused by biological factors such as age or gender, for which a baseline has not been established in Antarctic krill.
313

314

315

316

317

318

319

320

321

322

323

324

325

326

327

328

329

330

331

332

333

334

335

336

337

338

339

340

341

342

343

344

345

346

347

348

349

350

351

352

353

AQ3 54 


\section{Acetylcholinesterase}

Acetylcholinesterase activity between crustacean species seems to be inversely proportional to size. Previous studies have reported low basal activity of AChE in Euphausia superba, compared to smaller krill species (Minutoli et al. 2002). AChE activity exhibited in this study was slightly lower compared to reports from similarly sized crustacean species (Key and Fulton 2002; Bolton-Warberg et al. 2007; Lavarias et al. 2011). In the present study, the individual responses measured most likely reflect baseline levels. $\mathrm{AChE}$ is responsible for the breakdown of neurotransmitters allowing for normal neurological function. Although the inhibition of AChE is not typically associated with DDT and its metabolites, AChE inhibition has previously been observed in crustaceans following DDT exposure (MartinezTabche et al. 1999; Galindo-Reyes et al. 2000). There is a small body of research that brings into question the specificity of AChE inhibition to organophosphate and carbamate pesticides. Non-dose-dependent inhibition of AChE was noted in response to polycyclic aromatic hydrocarbon mixtures in Antarctic scallops (Bonacci et al. 2009), and metals have also been shown to inhibit AChE activity (Frasco et al. 2005). It is therefore recommended that AChE activity in $E$. superba be examined further, particularly in light of the low basal activity exhibited in this study. It may be valuable for future work to test if other organochlorine contaminants, including the parent metabolite DDT, and known AChE inhibitors such as chlorpyrifos, which was recently detected in Antarctic air and seawater (Bigot et al. 2016), can inhibit this enzyme in Antarctic krill.

\section{Glutathione peroxidase}

The absence of concentration-dependent response for GPx activity indicates the detection of baseline levels of GPx. Up-regulation of antioxidant enzymes would be expected if krill were experiencing oxidative stress relating to $p, p^{\prime}$ DDE exposure, i.e. oxidative stress would trigger increased production of antioxidant enzymes. In mammalian systems, $p, p^{\prime}$-DDE is known to cause oxidative stress through the generation of reactive oxygen species (Pérez-Maldonado et al. 2005). This response has also been noted in bivalves, for which the production of reactive oxygen species was suggested to be the main mode of toxicity (Dowling et al. 2006). The absence of a significant increase in GPx activity suggests that either: (a) GPx is unable to respond to the high level of $p, p^{\prime}$-DDE-induced reactive oxygen species in Antarctic krill i.e. an inefficiency of the system potentially capped by a limiting component such as glutathione co-factor (as noted in response to other organochlorines e.g. Numan et al. 1990) or, (b) the krill are not experiencing oxidative stress induced by $p, p^{\prime}$-DDE. As the assessment of oxidative stress indicators (such as lipid peroxidation or protein carbonyl content) were outside the scope of this study, it is difficult to conclude whether the krill were experiencing oxidative stress. Generally the antioxidant capacity of polar invertebrates is quite high (Regoli et al. 2000; Abele and Puntarulo 2004). Antarctic krill have been found to experience very little oxidative stress in response to hypoxia despite the absence of significant up-regulation of antioxidant enzymes, including GPx (Tremblay and Abele 2015). Previous studies have found that Antarctic krill exhibit high levels of low molecular weight antioxidants, reduced glutathione and vitamin E (Dunlap et al. 2002), which afforded adequate reactive oxygen species elimination through scavenging. It is possible that Antarctic krill may be able to cope with a $p, p^{\prime}$-DDE-mediated increase in reactive oxygen species under normal basal GPx expression due to the abundance of these other antioxidants.

\section{Detoxification capabilities of Euphausia superba}

The applied exposure concentrations, although in line with routine toxicity testing protocols, were appreciably higher than those measured in Antarctic seawater (Bigot et al. 2016). Interestingly, despite these artificially elevated concentrations, Phase II enzyme activity did not provide support for an induction of a detoxification response in the species. These findings correspond well with the observation of toxic effects expressed throughout the original behavioural experiment (Poulsen et al. 2012a). Enzymes of the cytochrome P450 complex are known to be induced by DDT and $p, p^{\prime}$-DDE in mammals (Nims et al. 1998), and may be better candidates for studying $p, p^{\prime}$-DDE detoxification in krill. Furthermore, CYPs have been associated with organochlorine insecticide resistance in crustaceans (Brausch and Smith 2009). DDT-resistant fairy shrimp treated with cytochrome P450 inhibitors became more sensitive to DDT-induced toxicity. It is possible that CYPs played a role in the apparent declining toxicity of $p, p^{\prime}$-DDE throughout the behavioural experiment, perhaps more so than the limited capacity expressed by GST. Despite the non-detectability of CYP2B, cytochrome $\mathrm{P} 450$ is a large and diverse group of enzymes and further study of other CYPs may provide insights into krill detoxification mechanisms.

An in-depth comparison of the detoxification capabilities between analogous species or contaminants is not possible due to an almost complete lack of published data in this field. Very little is known about polar crustacean detoxification capabilities. It has been suggested that polar species may be more susceptible to foreign chemical contaminants compared to tropical or temperate species (Chapman and Riddle 2005; Corsolini 2009; de Hoop et al. 2011), and that the detoxification capabilities of polar 
species are lower than temperate and tropical counterparts. This seems to be the case for fish (e.g. Strobel et al. 2015), but the limited number of studies on polar crustaceans present conflicting results. A recent study compared the GST detoxification capabilities of Arctic and sub-Arctic copepods exposed to marine diesel. Interestingly the Arctic species expressed an almost 25 times increase in GST following diesel exposure, whereas GST in the sub-Arctic species only expressed a twofold increase (Hansen et al. 2013). By contrast, a study on the same two species of copepod found the opposite trend when exposed to artificially weathered marine diesel (Hansen et al. 2011). Compared to temperate species, adaption to a polar climate has led to reduced metabolic rates (Peck 2002), which effectively delay the onset of toxicity (King and Riddle 2001; Payne et al. 2014). Reduced metabolism is thus also expected to delay detoxification, possibly explaining the absence of induced GST activity found in this study over a $96 \mathrm{~h}$ exposure timeframe. Wild krill are likely to be exposed over a long period of time. Chronic exposure studies may be needed to determine if the absence of significant up-regulation of GST is a function of delayed detoxification.

\section{Conclusions}

As a result of their unique adaptations to a cold climate, many biomarker responses for tropical or temperate species may not be directly comparable to polar species. True polar bio-indicator species are rare. To the authors' knowledge, this is the first time that the detoxification response of any polar crustacean has been assessed in response to organochlorine compound exposure. The findings presented here provide an important baseline for future work to establish the mechanisms of organochlorine toxicity and further our understanding of Antarctic krill detoxification capabilities. The activity of glutathione $S$-transferase, glutathione peroxidase and acetylcholinesterase do not to respond to $p, p^{\prime}$-DDE in a concentration-dependent manner in Antarctic krill.

Acknowledgements The authors would like to acknowledge Mr. Michael Arthur for assistance with statistical analysis. This work received partial funding from ARC Discovery Grant DP0666891. Amanda Dawson is supported by PHD scholarship from ARC Discovery DP140100018. We would like to thank the anonymous reviewers whose comments greatly improved this manuscript.

\section{Compliance with ethical standards}

Conflict of interest The authors declare no conflict of interest. All procedures performed involving animals were in accordance with the ethical standards of the institution at which the studies were conducted.

\section{References}

Abele D, Puntarulo S (2004) Formation of reactive species and induction of antioxidant defence systems in polar and temperate marine invertebrates and fish. Comp Biochem Physiol Part A 138:405-415. doi:10.1016/j.cbpb.2004.05.013

Atkinson A, Siegel V, Pakhomov E, Rothery P (2004) Long-term decline in krill stock and increase in salps within the Southern Ocean Nature 432:100-103. http://www.nature.com/nature/jour nal/v432/n7013/suppinfo/nature02996_S1.html

Bengtson Nash SM, Goddard J, Müller JF (2006) Phytotoxicity of surface waters of the Thames and Brisbane River Estuaries: a combined chemical analysis and bioassay approach for the comparison of two systems. Biosens Bioelectron 21:2086-2093. doi:10.1016/j.bios.2005.10.016

Bengtson Nash SM, Poulsen A, Kawaguchi S, Vetter W, Schlabach M (2008) Persistent organohalogen contaminant burdens in Antarctic krill (Euphausia superba) from the eastern Antarctic sector: a baseline study. Sci Total Environ 407:304-314. doi:10.1016/j. scitotenv.2008.08.034

Bengtson Nash SM, Waugh CA, Schlabach M (2013) Metabolic concentration of lipid soluble organochlorine burdens in the blubber of southern hemisphere humpback whales through migration and fasting. Environ Sci Technol 47:9404-9413. doi:10.1021/es401441n

Bhavan PS, Geraldine P/(2001) Biochemical stress responses in tissues of the prawn Macrobrachium malcolmsonii on exposure to endosulfan. Pestic Biochem Physiol 70:27-41

Bigot M, Muir DCG, Hawker DW, Cropp R, Dachs J, Teixeira CF, Bengtson Nash S (2016) Air-seawater exchange of organochlorine pesticides in the southern ocean between Australia and Antarctica. Environ Sci Technol 50:8001-8009. doi:10.1021/acs. est.6b01970

Bolton-Warberg M, Coen LD, Weinstein JE (2007) Acute toxicity and acetylcholinesterase inhibition in grass shrimp (Palaemonetes pugio) and oysters (Crassostrea virginica) exposed to the organophosphate dichlorvos: laboratory and field studies. Arch Environ Contam Toxicol 52:207-216. doi:10.1007/s00244-0050325-z

Bonacci S, Corsi I, Focardi S (2009) Cholinesterases in the Antarctic scallop Adamussium colbecki: characterization and sensitivity to pollutants. Ecotoxicol Environ Saf 72:1481-1488. doi:10.1016/j. ecoenv.2009.01.002

Brausch JM, Smith PN (2009) Mechanisms of resistance and crossresistance to agrochemicals in the fairy shrimp Thamnocephalus platyurus (Crustacea: Anostraca). Aquat Toxicol 92:140-145. doi:10.1016/j.aquatox.2009.02.002

Chapman PM, Riddle MJ (2005) Toxic effects of contaminants in polar marine environments. Environ Sci Technol 39:200A-206A

Clark AG, Shamaan NA (1984) Evidence that DDT-dehydrochlorinase from the house fly is a glutathione S-transferase. Pestic Biochem Physiol 22:249-261. doi:10.1016/0048-3575(84)90018-X

Clark MS, Thorne MA, Toullec J-Y, Meng Y, Peck LS, Moore S (2011) Antarctic krill 454 pyrosequencing reveals chaperone and stress transcriptome. PLoS ONE 6:e15919

Corsolini S (2009) Industrial contaminants in Antarctic biota. J Chromatogr A 1216:598-612. doi:10.1016/j.chroma.2008.08.012

Corsolini S, Kannan K, Imagawa T, Focardi S, Giesy JP (2002a) Polychloronaphthalenes and other dioxin-like compounds in Arctic and Antarctic marine food webs. Environ Sci Technol 36:3490-3496. doi:10.1021/es025511v

Corsolini S, Romeo T, Ademollo N, Greco S, Focardi S (2002b) POPs in key species of marine Antarctic ecosystem. Microchem J 73:187-193. doi:10.1016/S0026-265X(02)00063-2 
Corsolini S, Covaci A, Ademollo N, Focardi S, Schepens P (2006) Occurrence of organochlorine pesticides (OCPs) and their enantiomeric signatures, and concentrations of polybrominated diphenyl ethers (PBDEs) in the Adélie penguin food web. Antarctica Environ Pollut 140:371-382. doi:10.1016/j.envpol.2005.04.039

de Hoop L, Schipper AM, Leuven RSEW, Huijbregts MAJ, Olsen GH, Smit MGD, Hendriks AJ (2011) Sensitivity of polar and temperate marine organisms to oil components. Environ Sci Technol 45:9017-9023. doi:10.1021/es202296a

Dowling V, Hoarau PC, Romeo M, O'Halloran J, van Pelt F, O'Brien N, Sheehan D (2006) Protein carbonylation and heat shock response in Ruditapes decussatus following $\mathrm{p}, \mathrm{p}^{\prime}$-dichlorodiphenyldichloroethylene (DDE) exposure: a proteomic approach reveals that DDE causes oxidative stress. Aquat Toxicol 77:11-18. doi:10.1016/j.aquatox.2005.10.011

Dunlap WC, Fujisawa A, Yamamoto Y, Moylan TJ, Sidell BD (2002) Notothenioid fish, krill and phytoplankton from Antarctica contain a vitamin $\mathrm{E}$ constituent ( $\alpha$-tocomonoenol) functionally associated with cold-water adaptation. Comp Biochem Physiol B 133:299-305. doi:10.1016/S1096-4959(02)00150-1

Ellman GL, Courtney KD, Andres V, Featherstone RM (1961) A new and rapid colorimetric determination of acetylcholinesterase activity. Biochem Pharmacol 7:88-95. doi:10.1016/0006-2952 (61) $90145-9$

Enayati AA, Ranson H, Hemingway J (2005) Insect glutathione transferases and insecticide resistance. Insect Mol Biol 14:3-8. doi:10.1111/j.1365-2583.2004.00529.x

Flores H et al (2012) The association of Antarctic krill Euphausia superba with the under-ice habitat. PLoS ONE 7:e31775. doi:10. 1371/journal.pone.0031775

Frasco MF, Fournier D, Carvalho F, Guilhermino L (2005) Do metals inhibit acetylcholinesterase (AChE)? Implementation of assay conditions for the use of AChE activity as a biomarker of metal toxicity. Biomarkers 10:360-375. doi:10.1080/13547500500 264660

Galindo-Reyes J, Dalla Venezia L, Lazcano-Alvarez G, RivasMendoza H (2000) Enzymatic and osmoregulative alterations in white shrimp Litopenaeus vannamei exposed to pesticides. Chemosphere 40:233-237

Gaume B, Dodet N, Thomé J-P, Lemoine S (2014) Expression of biotransformation and oxidative stress genes in the giant freshwater prawn Macrobrachium rosenbergii exposed to chlordecone. Environ Sci Pollut Res 22:1-12. doi:10.1007/ s11356-014-3134-y

George JL, Frear DEH (1966) Pesticides in the Antarctic. J Appl Ecol 3:155-167. doi:10.2307/2401454

Habig WH, Pabst MJ, Jakoby WB (1974) Glutathione S-transferases: the first enzymatic step in mercapturic acid formation. J Biol Chem 249:7130-7139

Hansen BH, Altin D, Rørvik SF, Øverjordet IB, Olsen AJ, Nordtug T (2011) Comparative study on acute effects of water accommodated fractions of an artificially weathered crude oil on Calanus finmarchicus and Calanus glacialis (Crustacea: Copepoda). Sci Total Environ 409:704-709. doi:10.1016/j.scitotenv.2010.10.035

Hansen BH, Altin D, Øverjordet IB, Jager T, Nordtug T (2013) Acute exposure of water soluble fractions of marine diesel on Arctic Calanus glacialis and boreal Calanus finmarchicus: effects on survival and biomarker response. Sci Total Environ 449: 276-284. doi:10.1016/j.scitotenv.2013.01.020

Hassall KA (1990) The biochemistry and uses of pesticides: structure, metabolism, mode of action and uses in crop protection, 2nd edn. Wiley, Weinheim

Hoarau P, Gnassia-Barelli M, Romeo M, Girard J-P (2001) Differential induction of glutathione S-transferases in the clam Ruditapes decussatus exposed to organic compounds. Environ Toxicol Chem 20:523-529. doi:10.1002/etc.5620200310
Jemec A, Drobne D, Tisler T, Sepcic K (2010) Biochemical biomarkers in environmental studies-lessons learnt from enzymes catalase, glutathione S-transferase and cholinesterase in two crustacean species. Environ Sci Pollut Res Int 17:571-581. doi:10.1007/s11356-009-0112-x

Jemec A, Lešer V, Drobne D (2012) The link between antioxidant enzymes catalase and glutathione S-transferase and physiological condition of a control population of terrestrial isopod (Porcellio scaber). Ecotoxicol Environ Saf 79:42-47. doi:10. 1016/j.ecoenv.2011.11.040

Kawaguchi S et al (2011) Will krill fare well under Southern Ocean acidification? Biol Lett 7:288-291. doi:10.1098/rsbl.2010.0777

Key PB, Fulton MH (2002) Characterization of cholinesterase activity in tissues of the grass shrimp (Palaemonetes pugio). Pestic Biochem Physiol 72:186-192. doi:10.1016/S0048-3575(02)00006-8

King CK, Riddle MJ (2001) Effects of metal contaminants on the development of the common Antarctic sea urchin Sterechinus neumayeri and comparisons of sensitivity with tropical and temperate echinoids. Mar Ecol Prog Ser 215:143-154

Koenig S, Solé M (2012) Natural variability of hepatic biomarkers in Mediterranean deep-sea organisms. Mar Environ Res 79:122-131. doi:10.1016/j.marenvres.2012.06.005

Koenig S, Fernández P, Company JB, Huertas D, Solé M (2013) Are deep-sea organisms dwelling within a submarine canyon more at risk from anthropogenic contamination than those from the adjacent open slope? A case study of Blanes canyon (NW Mediterranean). Prog Oceanogr 118:249-259

Lavarias S, Heras H, Pedrini N, Tournier H, Ansaldo M (2011) Antioxidant response and oxidative stress levels in Macrobrachium borellii (Crustacea: Palaemonidae) exposed to the water-soluble fraction of petroleum. Comp Biochem Physiol, C 153:415-421. doi:10.1016/j.cbpc.2011.02.002

Lotufo GR, Landrum PF, Gedeon ML, Tigue EA, Herche LR (2000) Comparative toxicity and toxicokinetics of ddt and its major metabolites in freshwater amphipods. Environ Toxicol Chem 19:368-379. doi:10.1002/etc.5620190217

Lydy JM, Lasater LJ, Landrum FP (2000) Toxicokinetics of DDE and 2-chlorobiphenyl in Chironomus tentans. Arch Environ Contam Toxicol 38:163-168. doi:10.1007/s002449910021

Martinez-Tabche L, Romero Solis M, Lopez Lopez E, Galar Martinez M (1999) Toxic effect of DDT, chlordane and water from the Ignacio Ramirez dam (Mexico), on Daphnia magna (Crustacea: Daphnidae). Rev Biol Trop 47:681-690

Minutoli R, Fossi MC, Guglielmo L (2002) Evaluation of acetylcholinesterase activity in several zooplanktonic crustaceans. Mar Environ Res 54:799-804. doi:10.1016/S0141-1136(02)00116-2

Nicol S, Worby A, Leaper R (2008) Changes in the Antarctic sea ice ecosystem: potential effects on krill and baleen whales Mar Freshw Res 59:361-382. doi:10.1071/MF07161

Nims RW, Lubet RA, Fox SD, Jones CR, Thomas PE, Reddy AB, Kocarek TA (1998) Comparative pharmacodynamics of CYP2B induction by DDT, DDE, and DDD in male rat liver and cultured rat hepatocytes. J Toxicol Environ Health A 53:455-477

Numan IT, Hassan MQ, Stohs SJ (1990) Endrin-induced depletion of glutathione and inhibition of glutathione peroxidase activity in rats. Gen Pharmacol-Vasc S 21:625-628. doi:10.1016/03063623(90)91008-F

Payne SJ, King CK, Zamora LM, Virtue P (2014) Temporal changes in the sensitivity of coastal Antarctic zooplankton communities to diesel fuel: a comparison between single- and multi-species toxicity tests. Environ Toxicol Chem 33:882-890. doi:10.1002/ etc. 2522

Peck LS (2002) Ecophysiology of Antarctic marine ectotherms: limits to life. In: Arntz WE, Clarke A (eds) Ecological studies in the Antarctic Sea Ice Zone: results of easiz midterm symposium. 
Springer, Berlin, pp 221-230. doi:10.1007/978-3-642-59419-9_ 29

Pérez-Maldonado IN, Herrera C, Batres LE, González-Amaro R, Díaz-Barriga F, Yáñez L (2005) DDT-induced oxidative damage in human blood mononuclear cells. Environ Res 98:177-184. doi:10.1016/j.envres.2004.11.001

Poulsen AH, Kawaguchi S, Leppänen MT, Kukkonen JVK, Bengtson Nash SM (2011) Altered developmental timing in early life stages of Antarctic krill (Euphausia superba) exposed to p, $\mathrm{p}^{\prime}-$ DDE. Sci Total Environ 409:5268-5276. doi:10.1016/j.scito tenv.2011.08.056

Poulsen AH, Kawaguchi S, King CK, King RA, Bengtson Nash SM (2012a) Behavioural sensitivity of a key Southern Ocean species (Antarctic krill, Euphausia superba) to p,p'-DDE exposure. Ecotoxicol Environ Saf 75:163-170. doi:10.1016/j.ecoenv.2011. 09.005

Poulsen AH, Kawaguchi S, Kukkonen JVK, Leppänen MT, Bengtson Nash SM (2012b) Aqueous uptake and sublethal toxicity of p, $\mathrm{p}^{\prime}$ DDE in non-feeding larval stages of Antarctic krill (Euphausia superba). Environ Pollut 160:185-191. doi:10.1016/j.envpol. 2011.09.022

Poulsen AH, Landrum PF, Kawaguchi S, Bengtson Nash SM (2013) Dietary exposure of Antarctic krill to $\mathrm{p}, \mathrm{p}^{\prime}$-DDE: uptake kinetics and toxicological sensitivity in a key polar species. Environ Pollut 175:92-99. doi:10.1016/j.envpol.2012.12.026

Regoli F, Nigro M, Bompadre S, Winston GW (2000) Total oxidant scavenging capacity (TOSC) of microsomal and cytosolic fractions from Antarctic, Arctic and Mediterranean scallops: differentiation between three potent oxidants. Aquat Toxicol 49:13-25. doi:10.1016/S0166-445X(99)00070-3

Rewitz KF, Styrishave B, Løbner-Olesen A, Andersen O (2006) Marine invertebrate cytochrome P450: emerging insights from vertebrate and insect analogies. Comp Biochem Physiol C $143: 363-381$
Sánchez-Bayo F (2012) Insecticides mode of action in relation to their toxicity to non-target organisms. J Environ Anal Toxicol 4:4-8

Sladen WJ, Menzie CM, Reichel WL (1966) DDT residues in Adelie penguins and a crabeater seal from Antarctica. Nature 210: $670-673$

Strobel A, Burkhardt-Holm P, Schmid P, Segner H (2015) Benzo(a)pyrene metabolism and EROD and GST biotransformation activity in the liver of red- and white-blooded Antarctic fish. Environ Sci Technol 49:8022-8032. doi:10.1021/acs.est.5b00176

Tremblay N, Abele D (2015) Response of three krill species to hypoxia and warming: an experimental approach to oxygen minimum zones expansion in coastal ecosystems. Mar Ecol. doi:10.1111/maec. 12258

Tremblay N, Gomez-Gutierrez J, Zenteno-Savin T, Robinson CJ, Sanchez-Velasco L (2010) Role of oxidative stress in seasonal and daily vertical migration of three krill species in the Gulf of California. Limnol Oceanogr 55:2570-2584. doi:10.4319/lo. 2010.55.6.2570

Wania F, MacKay D (1996) Tracking the distribution of persistent organic pollutants. Environ Sci Technol 30:390A-396A. doi:10. $1021 / \mathrm{es} 962399 \mathrm{q}$

Waugh CA, Nichols PD, Schlabach M, Noad M, Bengtson Nash S (2014) Vertical distribution of lipids, fatty acids and organochlorine contaminants in the blubber of southern hemisphere humpback whales (Megaptera novaeangliae). Mar Environ Res 94:24-31. doi:10.1016/j.marenvres.2013.11.004

Wild S et al (2015) An Antarctic research station as a source of brominated and perfluorinated persistent organic pollutants to the local environment. Environ Sci Technol 49:103-112. doi:10. $1021 /$ es5048232

Livingstone DR (1991) Organic Xenobiotic Metabolism in Marine Invertebrates. In: Buttler PJ, Greger R, Mangum CP, Somero GN, Takahashi K, Weber RE (eds) Advances in Comparative and Environmental Physiology. Springer, Berlin, pp 45-185 